УДК 338. 48

\title{
MODELS OF INTEGRATED MARKETING COMMUNICATIONS OF TOURIST ENTERPRISES
}

\author{
L. Strashynska \\ National University of Food Technologies
}

T. Samonova

Kyiv University of Tourism, Economics and Law

\begin{tabular}{l}
\multicolumn{1}{c}{ Key words: } \\
Communications \\
integrated marketing \\
communications \\
Models of integrated \\
marketing \\
communications \\
Synergistic effect \\
\hline
\end{tabular}

Article history:

Received 10.07.2018

Received in revised form

31.07.2018

Accepted 23.08.2018

Corresponding author:

L. Strashynska

E-mail:

vip1967@ukr.net

\section{ABSTRACT}

The strategic competitive advantages of enterprises in the tourist services market are investigated, and it is determined that the formation of the strategy of marketing communications should be combined with the use of innovative ways and methods for managing the promotion of travel services.

The strategic goal of development of tourist sphere in Ukraine, which involves the use of mechanisms of macro regulation, rational methods of management and competent organization of promotion of tourism product, is formulated. Different points of view of researchers concerning definition of the essence of the concept of "communication" are analyzed and the author's definition of this concept is presented.

Various models of integrated marketing communications (G. Burnett and S. Moriarty, V. Buzina, A. Arlantseva and E. Popov) are analyzed and their advantages and disadvantages are described.

It is argued that the most successful model is the integrated marketing communications, aimed at the emergence of a synergistic effect with the successful combination of elements of marketing message, transmitted by various means of communication influence. It is proved that the prerequisites for the emergence of a synergistic effect of marketing communications are related not only and not so much with the possible integration of communication means by increasing the frequency of messages and increasing the coverage of the target audience of tourist enterprises, as with the presence of different types of thinking, perception and processing of information inherent in man, and also the difference between the stereotypes it has.

It is determined that most models, based on a variety of approaches to the IMC, are mainly analogous in nature, which does not allow tourism enterprises to conduct scenario calculations and to predict the dynamics of sales in the application of marketing communications. It is substantiated that for the enterprises of the sphere of tourism, where competition at the present stage becomes rather high, a more detailed model of the IMC is needed which will allow competently to compare the necessary systems of marketing communications and establish the relationship between marketing and internally brand communications.

DOI: $10.24263 / 2225-2924-2018-24-4-12$ 


\section{МОДЕЛІ ІНТЕГРОВАНИХ МАРКЕТИНГОВИХ КОМУНІКАЦІЙ ТУРИСТИЧНИХ ПІДПРИЕМСТВ}

\section{Л.В. Страшинська}

Національний університет харчових технологій

\section{Т.Б. Самонова}

Київський університет туризму, економіки і права

У статті досліджено стратегічні конкурентні переваги підприємств на ринку туристичних послуг, а також визначено, щзо формування стратегії маркетингових комунікацій повинно поєднуватись з використанням інноваційних иляхів і методів управління просуванням туристичних послуг.

Сформульовано стратегічну мету розвитку туристичної сфери в Украӥні, щзо передбачає використання механізмів макрорегулювання, рачіональних методів управління та грамотної організації просування туристичного продукту. Проаналізовано різні точки зору дослідників щзодо визначення сутності поняття «комунікація» та представлено авторське визначення.

Розглянуто різноманітні моделі інтегрованих маркетингових комунікаиій (Дж. Бернета та С. Моріарті, В. Бузина, А. Арланщевої та С. Попова) та охарактеризовано їхні переваги та недоліки.

Аргументовано, щзо найбільш вдалою є модель інтегрованих маркетингових комунікачій, спрямована на виникнення синергічного ефекту при вдалому поєднанні елементів маркетингового повідомлення, переданого різними засобами комунікаційного впливу. Доведено, щуо передумови виникнення синергічного ефекту маркетингових комунікацій пов'язані не тільки $і$ не стільки з можливим при інтеграчії засобів комунікащії збільшенням частоти повідомлень $і$ збільшенням охоплення изільової аудиторії туристичних підприємств, скільки з наявністю різних типів мислення, сприйняття й обробки інформації, притаманних людині, а також відмінністю наявних у неї стереотипів.

Визначено, щзо більшість моделей, базуючись на різноманітності підходів до IMК, мають переважно аналоговий характер, який не дає змоги туристичним підприємствам проводити сценарні розрахунки і прогнозувати динаміку продажів при застосуванні маркетингових комунікацій. Обгрунтовано, щуо для підприємств сфери туризму, де конкуренція на сучасному етапі стає досить високою, необхідна більш розгорнута модель IMК, яка дасть змогу грамотно зіставити необхідні системи маркетингових комунікацій і встановити взаємозв'язок між маркетинговими та внутрішньо фірмовими комунікаціями.

Ключові слова: комунікачії, інтегровані маркетингові комунікачій, моделі інтегрованих маркетингових комунікацій, синергічний ефект.

Formulation of the problem. The development of tourism in many countries is a priority direction of economic development. Strategic competitive advantage in the market of tourist services can not be won only on the basis of the specifics and features of the product, therefore, in today's conditions, the most important issues 
economists include are the formation of a strategy of marketing communications, the use of innovative ways and methods for managing the promotion of travel services from the initiators of communication activity to contact audiences. Taking into account the role of marketing communications in the activities of tourism enterprises, it remains important to determine their most optimal models.

Analysis of recent research and publications. Scientific publications testify that researchers pay attention to the problems of integrated marketing communications (IMC), which are covered in the works of such domestic scientists as A.V. Voicach, S.P. Gavrilyuk, Yu.A. Dainovsky, S.M. Illyashenko, O.L. Kanishchenko, V.G. Korolko, N.M. Lysytsya, T.I. Lukyanets, O.P. Luciy, A.F. Pavlenko, V.A. Pavlysh, T.O. Primak, E.V. Romat, T.I. Tkachenko and foreign - D. Aaakera, T. Ambler, W. Arensa, R. Batra, D. Burnet, K. Bove, L. Yu. Hermogenova, A. Deyana, A.B. Zvierintsev, G. Carter, F. Kotler, D. Myers, S. Moriarty, A.V. Naumova, G.G. Pocheptsova, S. Tannenbaum, B.F. Triassic, A. Troadeck, O.V. Tyunyukova, N.G. Fedko, F. I. Sharkov, D. Schultz, D. Yadin and others.

The methodological aspects of integrated marketing communications are discussed in the scientific literature mainly in relation to certain business entities, and the branch aspects have not received sufficient justification, in particular, the research models of marketing communications of tourist enterprises have not been fully studied. Although in this area there are separate editions of domestic authors, in particular O.M. Azaryana, N.I. Vedmid, T.O. Demuri, Yu.O. Karyagina S.V. Melnichenko, G.B. Munina, Ye.V. Samartzev, Z.I. Tymoshenko, N.V. Shumlyanskaya and others.

The purpose of the paper is to study the most well-known models of integrated marketing communications and adapt them for tourist enterprises.

Presentation of the main results of the study. The strategic goal of tourism development in Ukraine is to create a tourism product that is competitive on the domestic and world markets, which can not only satisfy the tourist needs of the country as much as possible, but also provide on this basis the integrated development of territories and their socio-economic interests while preserving ecological balance and historical and cultural environment. This adds an exclusive role to the tourist industry and includes:

- firstly - the use of certain mechanisms of macro regulation;

- secondly, the use of rational management methods;

- the third is the competent organization of promotion of a tourist product, which depends on a number of factors, among which a special place is occupied by marketing communications.

Life-saving sources of existence as a tourist area in general, and specifically for each tourist enterprise are marketing communications. The system of marketing communications covers the activities of the company aimed at:

- informing;

- persuasion and reminders of consumers about their services;

- stimulating their sales;

- creation of a positive image of the tourist enterprise.

Currently, the concept of integrated marketing communications is becoming increasingly popular in the world and in Ukraine, in particular. Integrated 
marketing communications fit into the system of marketing relations. This is due to the fact that the program of establishing stable customer relationships requires more than just advertising the product through the media. To implement such a program, it is necessary to use a fully integrated communication process that has a special synergistic effect due to the optimal combination of advertising, sales promotion, direct sales, public relations and other communication tools.

The term "communication" is associated with the Latin word "communis", which means "general". When we enter into communication with someone, we strive to establish with it some kind of community, unity, it means that we try to share information, thoughts on some kind of thing or to show our attitude to anything.

In economic literature, the notion of "communication" is defined mainly as the exchange of information between people for the formation of business relations. From an economic point of view, communications are considered as a mandatory business management tool. For example, F.I. Khmil [1, p.124] believes that communication is an exchange of information, in which the leader receives the information needed to make effective decisions and brings them to the attention of employees. O.E. Kuzmin [2, p. 16] adds that communications are processes of communication between employees, units, organs, etc. In other words, this is no less complicated process of ensuring the connection between the subjects of economic life, taking into account consumers (households, family members, etc.). Consequently, communication plays an important integration role in the management of the enterprise, aimed at achieving the goal of the organization.

D. Schultz and S. Tannenbaum [3, p. 48] call communication a means of cooperation, interaction, and ensuring the achievement of the goals of workers, organizations and society as a result of the fact that modern business is a complex production with collective labor and the use of significant resources. It follows that the concept of "communication" characterizes different processes.

Thus, we can conclude that this term is expressed by different processes, and therefore for a clear definition of the essence of communication in the management of the enterprise proposed a general definition of this term. Therefore, in the opinion of the authors, communication is the art of meaningful information transfer between individuals through various forms of communication, which is closely linked to leadership, corporate culture and motivation, and aims at achieving the goals of the enterprise.

In the last few years, the concept of integrated marketing communications has been actively modernized, which has replaced traditional outdated marketing. According to the definition of the American Association of Advertising Agencies, integrated marketing communication is a concept of planning of marketing communications related to the need to assess the strategic role of individual areas and to find the optimal combination of them to ensure clarity, the sequence of maximizing the impact of communication programs through the consistent integration of all individual calls [4, p. 325].

The hierarchy of the objectives of the enterprise, marketing and IMC is shown in Fig. 1. 


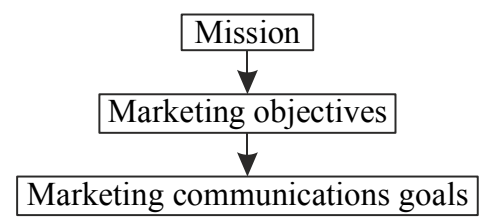

Fig. 1. Three levels of goals

Planning objectives from the top down determines the effectiveness of building the entire enterprise. All marketing communication goals should be for marketing purposes, and they, in turn, should be consistent with the mission of the enterprise. From the definition of the entire marketing system IMC models are being built.

The IMC model proposed by J. Burnett and S. Moriarty is based on the marketing plan and its purpose, which determines the interaction of elements of marketing-mix (Fig. 2).

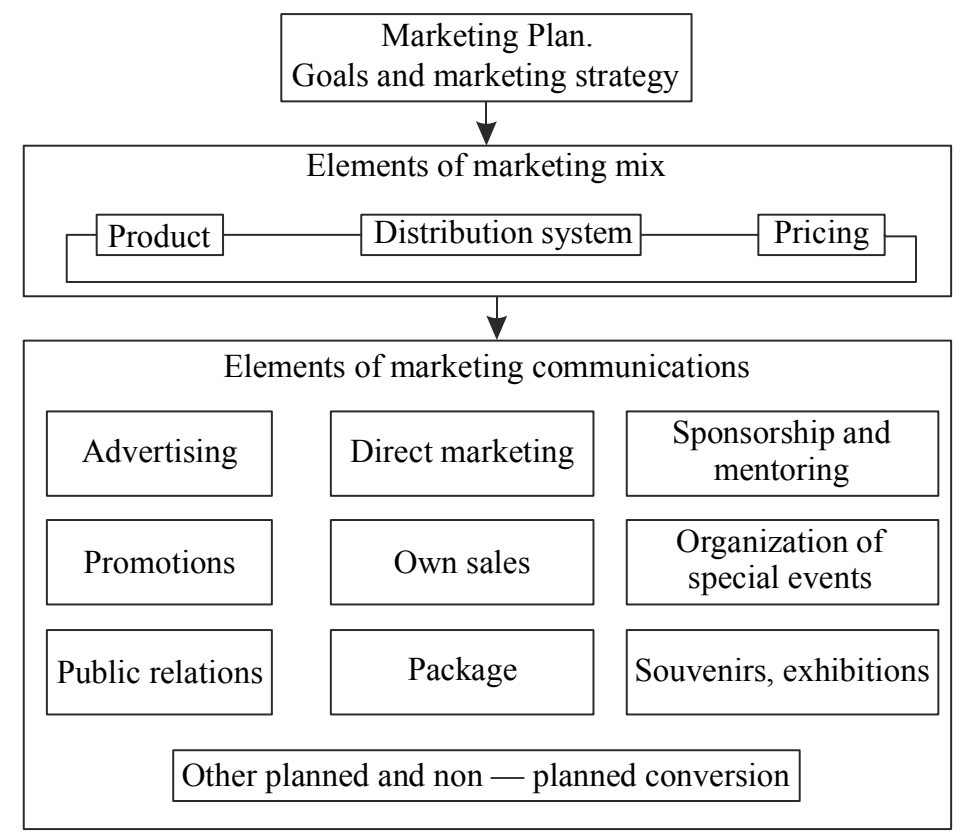

Fig. 2. IMC Model J. Burnett and S. Moriarty [5, p. 38]

In this model, integrated marketing communication is shown as the fourth element of a marketing mix that supports the other three. The second part of the model serves for a detailed reflection of the plan of marketing communications. This plan is based on the approach adopted for integrated marketing communications, which includes planned and unplanned marketing appeals.

Researchers argue that integrated marketing communication helps to create synergies by coordinating all types of communication activities in the formulation of agreed marketing appeals that are perceived and memorized by target audiences. 
As a result of the application of this model, the effectiveness of the marketing activity of the company increases, since the agreed appeals are more effective than independent and uncoordinated.

The most logical for the tourism industry is the concept of integrated marketing communications. This is due to the following features:

- the final transition of tourism enterprises to the differentiation of investment in marketing activities;

- high efficiency of integrated marketing communications;

- the orientation of integrated marketing communications for the long-term effect of marketing activities. This is beneficial for those tourism enterprises that build their marketing strategy for several years in advance due to forecasts and trends in consumer behavior.

In the case of tourist enterprises, the model of J. Burnett and S. Moriarty looks like this (Fig. 3).

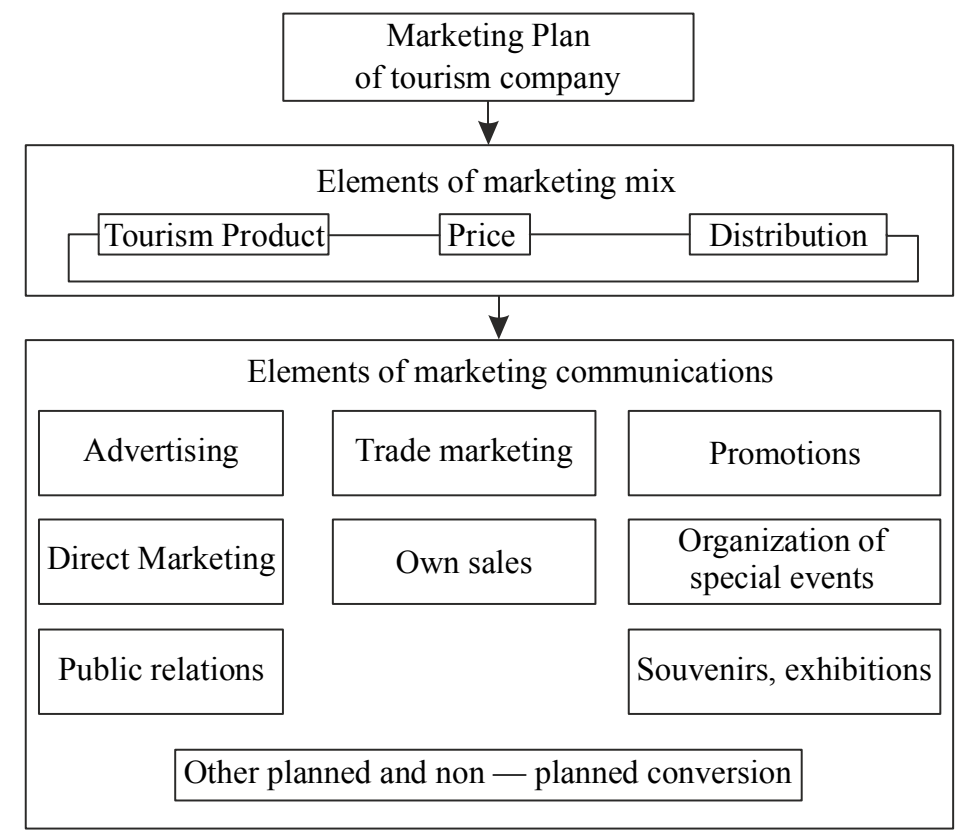

Fig. 3. IMC model J. Burnett and S. Moriarty (adapted for tourist enterprises)

A slightly different view of the IMC model is represented by V.I. Buzyn in the work "Fundamentals of Media Planning" (6, p.57). In his opinion, the IMC stems from the interaction of all communication elements of the enterprise, that is, the result of a joint action (Fig. 4). The advantages of this model include the allocation of intra-corporate communications and the emphasis on their relationship with other types of communications. However, its disadvantage, as in the preceding case, is mainly an analog nature of the model, which does not allow for scenariobased economic and mathematical calculations and predict the dynamics of sales of tourist services in the application of communication tools in the counter-strategy of competitors. 


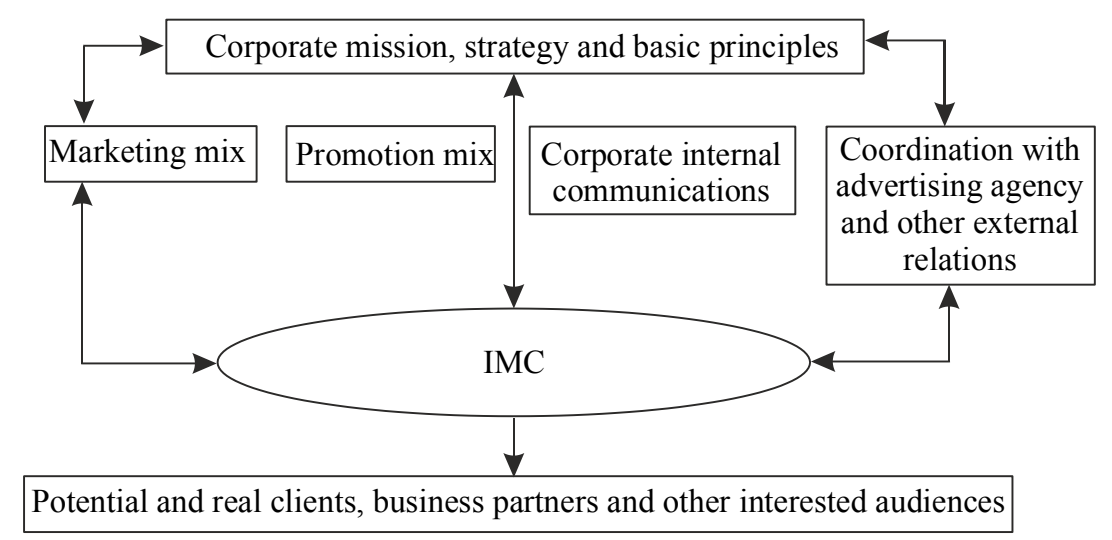

Fig. 4. Model of integrated marketing communications (by VI Buzin)

According to A.V. Arlantseva and Y.V. Popova, integrated marketing communications are aimed at the emergence of a synergistic effect, which can manifest itself at three levels:

- on the first level, a synergistic effect occurs when the interaction of the structural elements of one communication message, affecting the various channels of human perception (vision, hearing, sense of smell, touch). So, TV ads can be more effective than radio advertising because of actions on the audience, both with the help of images and audio. In this case, the magnitude and direction of the effect directly depend on the stereotypes available to the object of influence, as well as the degree of their expression;

- at the second level, the synergistic effect manifests itself from the complex use of the elements of the advancement complex. Thus, advertising and sales promotion measures have a greater effect than sharing, rather than individual use of advertising and the separate promotion of sales, due to the appearance of the "ratchet effect", which is a manifestation of a synergistic effect;

- at the third level, the synergistic effect is enhanced when the communication resources of all elements of the marketing complex are used in promotion $(7, \mathrm{p} .14)$.

Model of Integrated Marketing Communications A.V. Arlantseva and Y.V. Popov, adapted for tourist enterprises, is presented in fig. 5 .

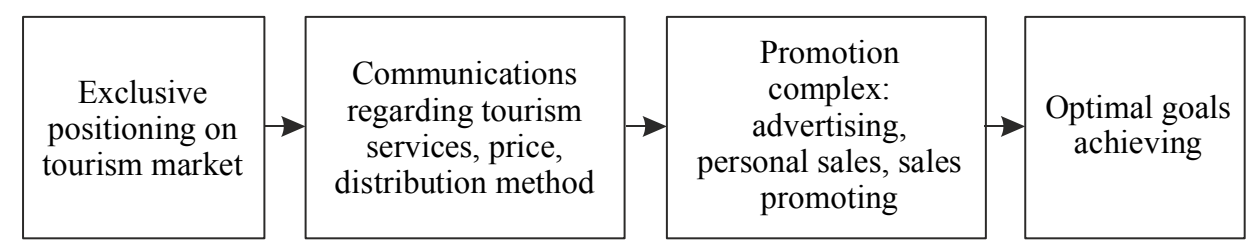

Fig. 5. Model of integrated marketing communications, adapted for tourist enterprises (by A. Arlantsev and Y. Popov)

Thus, in general, a synergistic effect occurs when a successful combination of elements of a marketing message transmitted by various means of communication influence. The prerequisites for the emergence of a synergistic effect of marketing communications are not only and not so much as possible with the integration of 
communication tools by increasing the frequency of messages and increasing the coverage of the target audience of tourism enterprises, as with the presence of different types of thinking, perception and processing of information inherent in man, as well as the difference between available stereotypes.

\section{Conclusions}

The three models under consideration emphasize the diversity of approaches to the IMC, but they are mostly analogous in nature, which does not allow tourism enterprises to conduct scenario calculations and predict the dynamics of sales in the application of marketing communications. For enterprises in the field of tourism, where competition at the present stage becomes quite high, a more detailed model of the IMC is needed, which will allow competently to compare the necessary marketing communication systems and establish the relationship between marketing and internally branded communications.

The need to focus its activities using IMC is especially relevant for tourist enterprises, since they are facing serious competition on the basis of a regional or international market. To succeed you need to use modern marketing methods, while flexibly and promptly using all possible means of marketing communications. The use of integrated marketing communications allows you to establish contact with the consumer, contributing to a two-way dialogue between tourism service providers and consumers. Integrated marketing communications allow you to create communications on the "order", to match the preferences of individual groups of consumers. These features allow tourism companies to establish more productive connections with consumers of services and save on their promotion.

\section{Literature}

1. Khmil F.I. Fundamentals of Management: Textbook. - 2nd. / F.I. Hop. - Kyiv : Akademvydav, 2007. - $576 \mathrm{pp}$.

2. Kuzmin O.I. On the Way to Victory or How to Become a People's Elect. / O.I. Kuzmin, A.I. Efimov — St. Petersburg : Izv. Sev.-Zap. acad. state service, 1998. — 92 p.

3. Schultz D.E. New Marketing Paradigm: Integrative Marketing Communications / D.E. Schultz, SI Tannenbaum, R.F. Lauterborn - Moscow : Infra-M, 2004. - 232 p.

4. Nedyak I.L. Political Marketing: The Fundamentals of Theory / I. L. Nnedak. - Moscow : All World, 2008. - $352 \mathrm{p}$.

5. Bernet J., Moriarty S. Marketing Communications: An Integrated Approach / Translation from English. ed. S.G. Bozhuzh. — St. Petersburg : Peter, 2001. — 864 p.

6. Buzyn V.I. Fundamentals of media planning / V.I. Buzyn - Moscow : Mir, 2002. - P. 57.

7. Arlantsev A.V. Synergism of Communication Instrumentation / A.V. Arlantsev, E.V. Popov // Marketing in Russia and abroad. — \# 1. — 2001. — P. 14. 